\title{
ПРО ВЗАЕМОЗАЛЕЖНІСТЬ СТАНОВЛЕННЯ МАНГУСЬКОЇ СТРУКТУРИ ПРИАЗОВСЬКОГО МЕГАБЛОКУ УКРАЇНСЬКОГО ЩИТА ТА РУДНИХ ПОКЛАДІВ В ЇЇ ОБ'ЄМІ
}

Осьмачко Л. С.

\section{ВСТУП}

Актуальність досліджень визначається необхідністю розвитку сировинної бази металевих корисних копалин, від яких залежить енергетичне та стратегічне забезпечення піднесення економіки України. Насамперед це уран-торієва сировина $(\mathrm{U}-\mathrm{Th})^{1}$.

Мета роботи - встановлення закономірностей розміщення родовищ металевих корисних копалин (насамперед урану та торію) залежно від факторів формування докембрійського структурного плану Українського щита (УЩ).

Об'єкт дослідження - докембрійський структурний план центральної частини Приазовського мегаблоку УЩ у зв'язку із закономірностями зосередження U-Th-родовищ.

Предмет дослідження - структурно-речовинні особливості будови та локалізації U-Th- рудопроявів Мангуської структури УЩ.

Методи дослідження. В основу досліджень покладено теоретичні уявлення та принципи структурно-парагенетичного аналізу. Вони розроблялися Є.I. Паталахою, О.І. Лукієнком, Б.М. Чіковим, O.I. Слензаком, О.I. Чередниченком, В.М. Венедиктовим, Г.В. Тохтуєвим, П.С. Верем’євим， А.Н. Казаковим， В.С. Заїка-Новацьким， О.Б. Гінтовим, С.В. Горяйновим. Зазначений аналіз враховує морфологічну оцінку і просторові характеристики взаєморозміщення дислокаційних утворень, їхній речовинний склад й Р-Т умови формування, дані про вік та послідовність становлення.

Короткий огляд будови об'єкта досліджень за даними попередників. Мангуський синклінорій за «Кореляційною схемою» ${ }^{2}-$ структура, за «Тектонічною картою» ${ }^{3}$ - Центральноприазовська

${ }^{1}$ Перспективи розвитку торієвої сировинної бази ядерної енергетики України / В.Г. Верховцев, А.В. Кузьмін, М.О. Ярощук, О.О. Крамар, Є.Б. Краснов, Г.В. Лисиченко, Л.С. Осьмачко, К.Г. Сущук та ін. Київ : Наукова думка, 2017. 269 с.

2 Кореляційна хроностратиграфічна схема раннього докембрію Українського щита / Єсипчук К.Ю., Бобров О.Б., Степанюк Л.М. та ін. УкрДГРІ. Київ, 2004.

3 Тектонічна карта України. Масштаб 1:1 000000 та пояснювальна записка / Мін-во охорони навколишнього природного середовища України. Державна геологічна служба / Круглов С.С., Арсірій Ю.О., Веліканов В.Я. та ін. Київ : УкрДГРІ, 2007. 
синклінорна зона розмежовує Приазовський мегаблок УЩ на СхідноПриазовський та Західно-Приазовський блоки I-го порядку ${ }^{4}$ (або Західноприазовську та Східноприазовську антиклінорні зони). Центральноприазовську синклінорну зону від Східноприазовської антиклінорної зони відділяе Малоянісольська розломна система, зчленування Західноприазовської антиклінорної та Центральноприазовської синклінорної зон розломами також порушене, але вони не $\epsilon$ безпосередньою межею $30 \mathrm{H}^{5}$.

За Г.Л. Кравченком та Р.М. Полуновським ${ }^{6,7}$, Мангуський синклінорій у першому наближенні має ромбовидну форму 3 простяганням вісі І-го порядку в субмеридіональному напрямі, довжина якої сягає 50 км. Синклінорій характеризується асиметричною будовою, широким розмахом крил - 45-50 км і крутим їх падінням.

Мангуський синклінорій виповнений переважно породами центральноприазовської серії неоархею, в підпорядкованій мірі західноприазовської серії палеоархею, також гранітоїдами анадольського, обіточненського й інших комплексів. Західноприазовська антиклінорна зона, навпаки, переважно сформована породами західноприазовської серії. Для Східноприазовської антиклінорної зони характерною є наявність численних інтрузивно-магматичних утворень палеопротерозою ${ }^{8}$.

Центральноприазовську синклінорну зону від Західно- й Східноприазовської антиклінорних зон, окрім зазначеного, чітко вирізняс різна геометрія складчастих форм. Для першої це парагенезис різнопорядкових вузьких, нерідко ізоклінальних (особливо більш високого порядку) лінійного типу складок субмеридіонального простягання, ускладнених численними поздовжніми, поперечними та діагональними розривними порушеннями. В антиклінорних зонах складчасті форми першого порядку близькі до брахіальних. Їх ускладнюють системи стиснених складок вищих порядків із крутими нахилами осьових поверхонь та відносно пологим, як правило, заляганням дзеркала складчастості ${ }^{9}$.

${ }^{4}$ Геология и металлогения докембрия Украинского щита. Комплект карт масштаба 1:100 000. Обьяснительные записки / Галецкий Л.С., Горлицкий Б.А., Кипнис Л.А., Клочков В.М., Колосовская В.А. и др. Киев. Мин-во геологии УССР, 1984.

Тектонічна карта України. Масштаб 1:1000 000 та пояснювальна записка / МОН природного середовища України. Державна геологічна служба / Круглов С.С., Арсірій Ю.О., Веліканов В.Я. та ін. Київ: УкрДГРІ, 2007.

К Кравченко Г.Л. До питання про тектоніку Північного Приазов'я. Геологічний журнал. 1965. Т. ХXV, Вип. 3. С. 56-65.

Полуновский Р.М. Литолого-петрографические особенности, стратиграфия и металлогения гнейсовой серии Центрального Приазовья : автореф. дис. ... канд. геол.-мин. наук : 04.00.01 / ІГФМАНУ. Київ, 1970. 24 с.

Кореляційна хроностратиграфічна схема раннього докембрію Українського щита / Єсипчук К.Ю., Бобров О. Б., Степанюк Л. М. та ін. УкрДГРІ. К., 2004.

${ }_{9}$ Тектонічна карта України. Масштаб 1:1000 000 та пояснювальна записка / Мін-во охорони навколишнього природного середовища України. Державна геологічна служба. Круглов С.С., Арсірій Ю.О., Веліканов В.Я. та ін. Київ : УкрДГРІ, 2007. 
Мангуська структура (структурно-формаційна зона), за авторами ${ }^{10}$, відповідає активній континентальній окраїні області розтягу при зіткненні Приазовського i Придніпровського мегаблоків (мікроконтинентів) у верхньому археї, а в подальшому - субдукції Придніпровського мікроконтиненту під Приазовський на нижньопротерозойський час. Мангуська структура виділяється як низькоомна зона і є областю перманентного (різновікового) розтягнення-стискування кори, тобто зоною інтенсивної переробки епіархейського фундаменту.

За С.В. Горяйновим зі співавторами, структура кристалічного фундаменту Приазовського мегаблоку «сложена последовательно пересекающими друг друга разновозрастными метаморфическими меланжами. Более ранние из них выступают для более поздних исходным субстратом и иногда сохраняются в виде реликтов. Такую структуру как целое можно назвать структурой последовательных дислокаций» ${ }^{11}$. Ці автори виділяють 6 етапів формування такої структури.

\section{1. Структурно-речовинна організація західного крила Мангуського синклінорію}

У західній частині Мангуської структури були проведені детальні геолого-структурні дослідження (рис. 1), результати яких були представлені в роботах ${ }^{12,13}$. В узагальнюючому вигляді результати зазначених досліджень полягають у тому, що Мангуський синклінорій $\epsilon$ гібридною дислокаційною структурою, яка формувалася щонайменше у вісім етапів тектоно-метаморфогенних трансформацій кристалічного фундаменту. Про це свідчать виділені в об'ємі синклінорію дислокаційні структури восьми генерацій. Вони на мікро-, мезорівнях організації синклінорію представлені смугастістю, сланцюватістю, мінеральною лінійністю, розлінзуванням, будинажем, кліважем, тріщинами, на макрорівні - в'язкими й крихкими розломами. Всі вони $є$ похідними від здвигових трансформацій, формувалися послідовно в часі при змінах напрямів тектонічних напруг та за різних Р-Т значень. Зокрема, структури генерацій 1-5, 7 є результатом спрямованої перекристалізації й фракціювання речовини кристалічного фундаменту в динамічних умовах

10 Геолого-геоэлектрическая модель Орехово-Павлоградской шовной зоны Украинского щита / Азаров Н.Я., Анциферов А.В., Шеремет Е.М., Глевасский Е.Б. и др. Киев : Наук. думка, 2005. 190 с.

11 Метаморфические и метасоматические комплексы Приазовья и Южного Донбасса / Горяйнов С.В., Коренев В.В., Аксенов С.В. и др. Харьков : Экограф, 2009.303 c.

$1 \dot{2}$ Осьмачко Л.С. Західне крило Центрально-Приазовської синформи - складна дислокаційна структура. Вісник Київського нащіонального університету імені Тараса Шевченка. Сер. Геологія. 2003. № 25. С. 42-44.

13 Осьмачко Л.С. Типи, умови та етапи формування дислокаційної тектоніки Сорокинської зони та ії обрамлення (із позицій тектонофаціального аналізу) : дис. ... канд. геол. наук : 04.00.04 «Геотектоніка». Київ, 2004. 189 с. 
за Р-Т показників на рівні від гранулітової до зеленосланцевої фацій метаморфізму; структури генерацій $6,8 \in$ постметаморфічними.

За даними ${ }^{14,15,16,17}$, для приазовської частини УЩ відомі цифри ізотопного віку кристалічних порід у діапазоні від 3,6 до 1,8 млрд років. 3 огляду на те, що досліджувані структури перших п’яти генерацій сформовані метаморфогенними мінералами й їх агрегатами, зазначені цифри віку вважаємо такими, що відповідають моментам прояву тектонічних трансформацій.

У цій роботі задля встановлення структурних закономірностей знаходження й умов формування перспективних ділянок на уран, торій та деякі інші корисні копалини в межах Мангуської структури нами були систематизовані дані щодо іiі петро-структурної організації. Систематизація полягала в опрацюванні фактичного матеріалу щодо розміщення смугастості, лінійності й інших метаморфогенних структур за допомогою програми StereoNett 2.46, охарактеризуванні осьової частини Мангуської структури відповідно до принципу ієрархічності геоструктур. Для такої систематизації вибрана осьова частина Мангуської структури, тому що, за даними ${ }^{18,19}$, в «ядрі синклінорію» відомі радіоактивні прояви уранової та уран-торієвої природи (рис. 1). Останні приурочені до Первомайської складчастої форми. Також у межах західного (р. Берда) та східного крил (р. Кальчик) синклінорію (рис. 1) знаходяться $\mathrm{Nb}, \mathrm{Ta}, \mathrm{Zr}(\mathrm{TR})$ та інші рудопрояви ${ }^{20,21}$.

14 Кореляційна хроностратиграфічна схема раннього докембрію Українського щита / Єсипчук К.Ю., Бобров О.Б., Степанюк Л. М. та ін. УкрДГРІ. Київ, 2004.

15 Державна геологічна карта України. М-б 1:200 000. Центральноукраїнська серія. L-37-VIII (Маріуполь), L-37-IX (Таганрог) / Б.В. Бородиня, І.Л. Князькова, Т.Я. Іваненко та ін. Київ : Державна служба геології та надр України, УкрДГРІ, КП «Південукргеологія», 2012.

16 Щербак Н.П., Артеменко Г.В., Лесная И.М. и др. Геохронология раннего докембрия Украинского щита (протерозой). Киев : Наук. думка, 2008. 240 с.

17 State geological map of Ukraine. Scale 1:200 000. Central-Ukrainian series map sheet L-37-VII (Berdyansk). Explanatory notes / Ministry of Ecology and Natural Resources of Ukraine; State geological Survey; State Enterprise «Pivdenukrgeologia» et al. Borodynya B.V., Knyazkova I.L., Esypchuk K.Yu. et al. Kyiv-2004 (2008).

18 Державна геологічна карта України. М-б 1:200 000. Центральноукраїнська серія. L-37-VIII (Маріуполь), L-37-IX (Таганрог) / Б.В. Бородиня, І.Л. Князькова, Т.Я. Іваненко та ін. Київ: Державна служба геології та надр України, УкрДГРІ, КП «Південукргеологія», 2012.

19 Закономерности образования и размещения урановых месторождений Украины / Редакционная коллегия: Я.Н. Белевцев, В.Ю. Фоменко, Б.И. Горошников и др. Авторы: М.Я. Абдулина, Л.И. Авдеева, Д.Е. Айзенберг и др. Киев : АН УССР, МИНГЕО СССР, 1968. $763 \mathrm{c.}$

${ }^{20}$ Металогенічна карта України. М-б 1:1000 000 / Гол. редактор Д.С. Гурський, автори: В.А. Колосовська, В.А. Веліканов, А.С. Войновський та ін. Держгеолслужба України, 20026 л.

${ }^{21}$ State geological map of Ukraine. Scale 1:200 000. Central-Ukrainian series map sheet L-37-VII (Berdyansk). Explanatory notes / Ministry of Ecology and Natural Resources of Ukraine; State geological Survey; State Enterprise «Pivdenukrgeologia» et al. Borodynya B.V., Knyazkova I.L., Esypchuk K.Yu. et al. Kyiv-2004 (2008). 


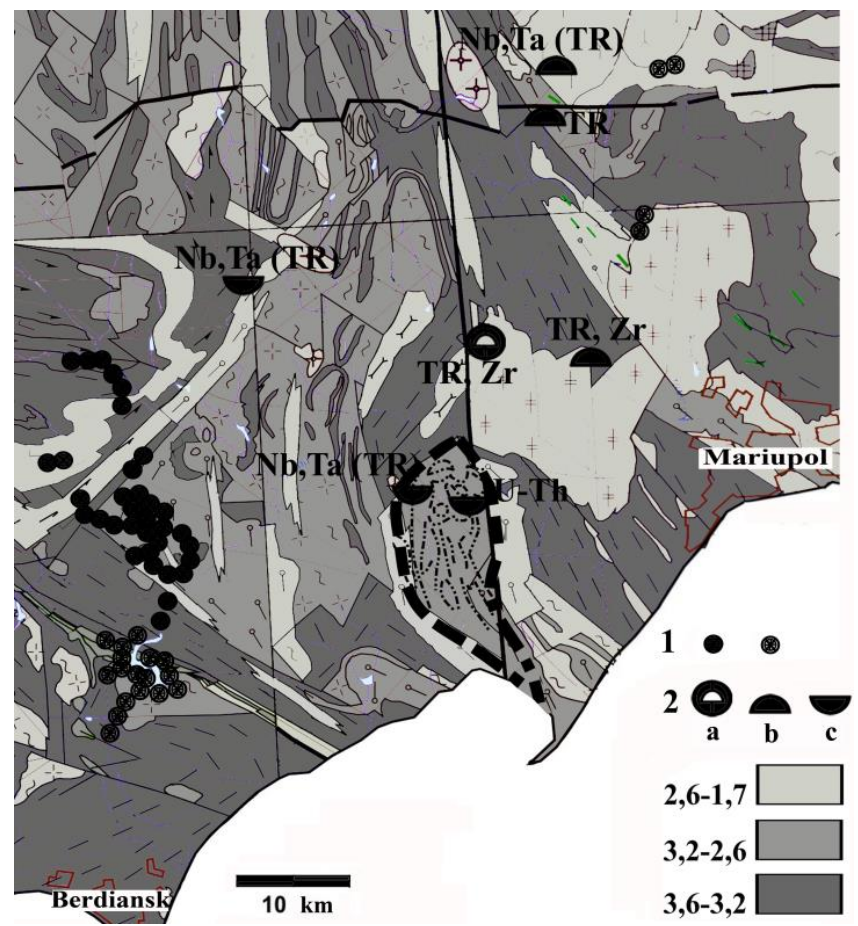

Рис. 1. Оглядова карта досліджень на основі ${ }^{22,23} .1$ - ділянки детальних робіт, дані за якими наведені в роботі (a) та дані за якими не наведені, але залучені до узагальнення та висновків (b). 2 - родовища (a) та рудопрояви (b, c) U-Th, TR- та комплексних-TR корисних копалин, $3^{24,25}$. Внизу праворуч - вікова шкала в млрд роках. Жирним пунктиром виділено ядро Мангуського синклінорію, про яке йтиметься нижче

\footnotetext{
${ }^{22}$ Кічурчак В.М., Пігулевський П.Г. Геолого-формаційна карта південно-східної частини УЩ. М 1:500 000. Міністерство охорони навколишнього природного середовища України. ДГП «УкрГеофізика». ДГЕ «ДніпроГеофізика». Київ. 2003.

${ }_{23}^{23}$ Металогенічна карта України. М-б 1:1000 000 / Гол. редактор Д.С. Гурський, автори: В.А. Колосовська, В.А. Веліканов, А.С. Войновський та ін. Держгеолслужба України, 20026 л.

${ }_{24}$ Металогенічна карта України. М-б 1:1000 000 / Гол. редактор Д.С. Гурський, автори: В.А. Колосовська, В.А. Веліканов, А.С. Войновський та ін. Держгеолслужба України, 20026 л.

${ }_{25}$ Державна геологічна карта України. М-б 1:200 000. Центральноукраїнська серія. L-37-VIII (Маріуполь), L-37-IX (Таганрог) / Б.В. Бородиня, І.Л. Князькова, Т.Я. Іваненко та ін. Київ : Державна служба геології та надр України, УкрДГРІ, КП «Південукргеологія», 2012.
} 
На рис. 2 наведені стереограми полюсів площин смугастості й сланцюватості (a) та занурення мінеральної лінійності (b) для дислокаційних структур генерації $0-1$. Вони речовинно представлені мігматитами, що сформовані мінеральними парагенезисами гранулітової фації метаморфізму. Вік структур цього етапу ми прив'язуємо до часу $3,6-3,4$ млрд років ${ }^{26}$. Вони формують реліктові смуго-, лінзоподібні тіла різноманітних розмірів серед дислокаційних структур наступних генерацій (рис. 3).

На стереограмі (рис. 2) розміщення власне структур генерації 0-1 та напрями дії тектонічних зусиль при їх становленні відображено індексом - 1. 3 рис. 2 видно, що становлення дислокаційних структур генерації 0-1 відбувалося при ротації напрямів дії тектонічних тисків, що зафіксовано в переорієнтації й залученні структур цієї генерації до молодших тектонічних проявів. Останні та утворені при цьому площини смугастості i сланцюватості та мінеральна лінійність відображені під індексами 2-5. Діаграма орієнтації оптичних осей кварцу $^{27}$ за результатами замірів (195) на федорівському столику зі смугастості гранітного складу структур цієї генерації відображає подібні результати, а саме: поля проекцій оптичних осей кварцу формують потрійний максимум в діапазоні нахилу $30-60^{\circ}$ та $0-20^{\circ}$.

Показовими є дані розміщення мінеральної лінійності меланосоми складу кристалосланців. Її розміщення фактично є трендом міграції в часі і просторі як лінійності, так і напрямів зміщення.

На рис. 4 наведена стереограма полюсів площин смугастості й сланцюватості для дислокаційних структур генерації-2. Вони речовинно представлені гнейсами й граніто-гнейсами, що сформовані мінеральними .. парагенезисами грануліт-амфіболітової фації метаморфізму. Їх формування ми прив'язуємо до часу $3,2-3,1$ млрд років тому ${ }^{28,29}$. Структури цієї генерації розвиваються за давнішим утворенням та формують реліктові лінзоподібні тіла серед дислокаційних структур наступних генерацій.

3 рис. 4 видно, що становлення дислокаційних структур генерації-2 також відбувалося під час ротації напрямів дії тектонічних напруг.

Діаграма орієнтації оптичних осей кварцу 3 гранітогнейсів за результатами замірів (230) на федорівському столику відображає

${ }^{26}$ Кореляційна хроностратиграфічна схема раннього докембрію Українського щита / Єсипчук К.Ю., Бобров О.Б., Степанюк Л.М. та ін. УкрДГРІ. Київ, 2004.

27 Осьмачко Л.С. Типи, умови та етапи формування дислокаційної тектоніки Сорокинської зони та іï обрамлення (із позицій тектонофаціального аналізу) : дис. ... канд. геол. наук : 04.00.04 «Геотектоніка». Київ, 2004. 189 с.

28 Кореляційна хроностратиграфічна схема раннього докембрію Українського щита / Єсипчук К.Ю., Бобров О.Б., Степанюк Л.М. та ін. УкрДГРІ. Київ, 2004.

Метаморфические и метасоматические комплексы Приазовья и Южного Донбасса / Горяйнов С.В., Коренев В.В., Аксенов С.В. и др. Харьков : Экограф, 2009. $303 \mathrm{c}$. 
подібні результати ${ }^{30}$, а саме: проекції оптичних осей кварцу формують неправильні кругові поля в діапазоні нахилу 0-30 та 40-60.

На рис. 5 наведені стереограми полюсів площин смугастості й сланцюватості (a) та занурення мінеральної лінійності (b) для дислокаційних структур генерації-3. Вони (басейн р. Берестової, прав. притоки р. Берди) речовинно представлені різнозернистими білими гранітоїдами та польовошпатовими кварцитами (рис. 6, 7). Ці тіла сформовані мінеральними парагенезисами амфіболітової фації метаморфізму.
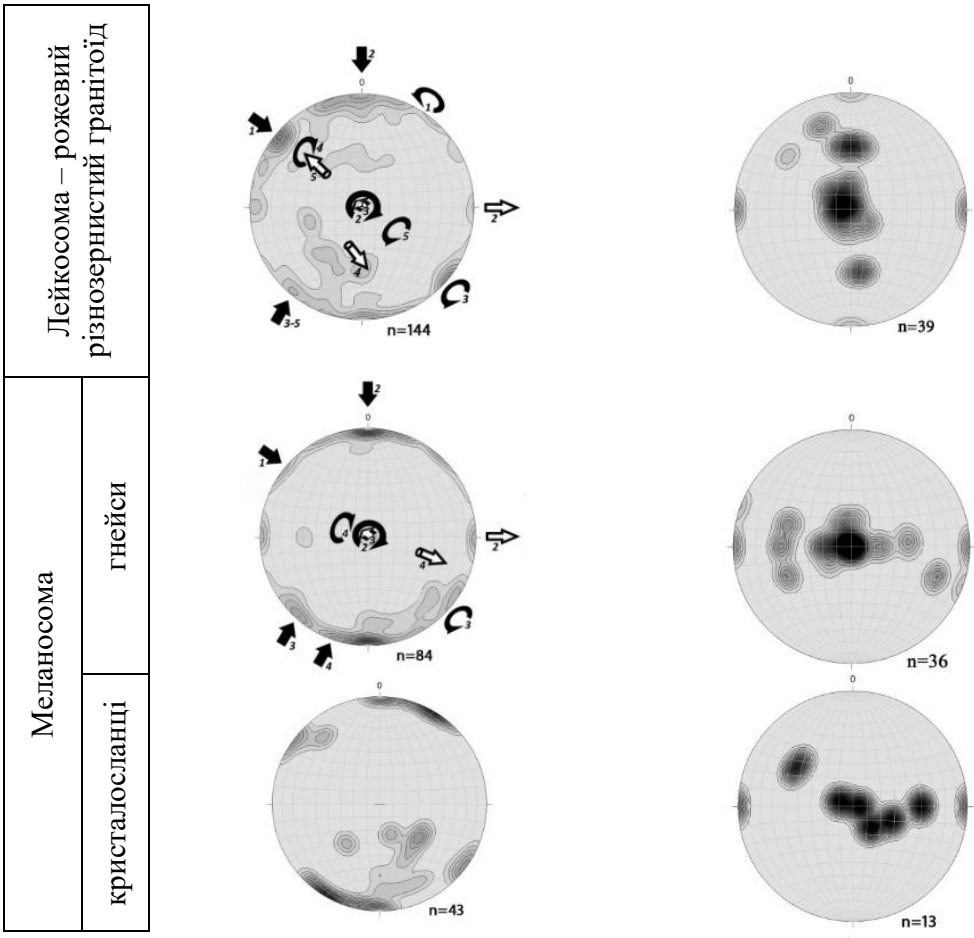

a

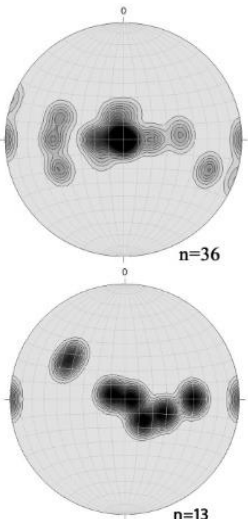

b

Рис. 2. Стереограми полюсів площин смугастості й сланцюватості (a) та занурення мінеральної лінійності (b) для дислокаційних структур генерації 0-1. Проекція на нижню півсферу. Градація ізоліній: 1-2-3-4-5-6-7-8-9-10-11-12-13-14-15. Стрілки - напрями дії тектонічних тисків: чорні прямі - стиснення, білі - розтягу; округлі - ротації. Цифри поруч - індекс етапу. $n$ - кількість замірів

30 Осьмачко Л.С. Типи, умови та етапи формування дислокаційної тектоніки Сорокинської зони та іiі обрамлення (із позицій тектонофаціального аналізу) : дис. ... канд. геол. наук : 04.00.04 «Геотектоніка». Київ, 2004. 189 с. 


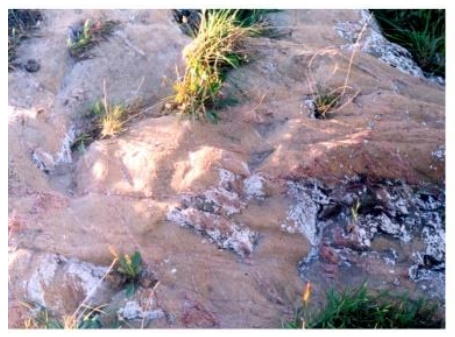

a

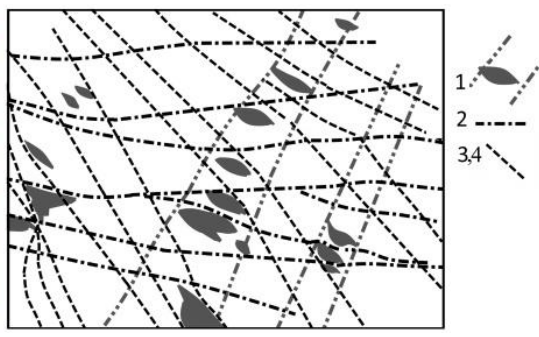

b

Рис. 3. Фрагмент перетину дислокаційних структур декількох генерацій (р. Берестова): а - фото зорієнтоване щодо сторін світу

(площина горизонтальна), b - теж зображено схематизовано, де 1-4 - дислокаційні структури відповідних генерацій

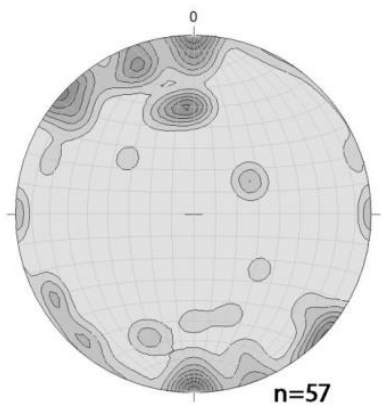

Рис. 4. Стереограма полюсів площин смугастості й сланцюватості для дислокаційних структур генерації-2. Інші позначення див. рис. 2

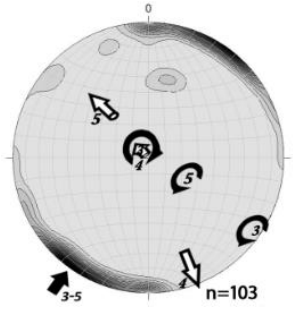

a

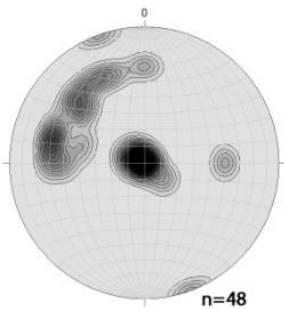

b

Рис. 5. Стереограми полюсів площин смугастості й сланцюватості

(a) та занурення мінеральної лінійності (b) для білих різнозернистих гранітів та кварцитів польовошпатових, що показані нижче. Інші позначення див. вище 


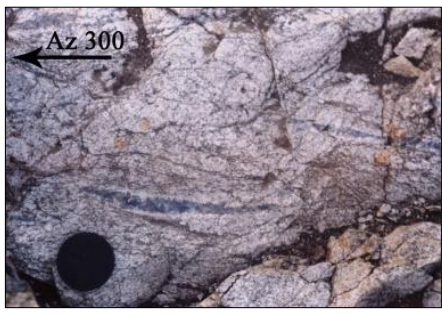

a

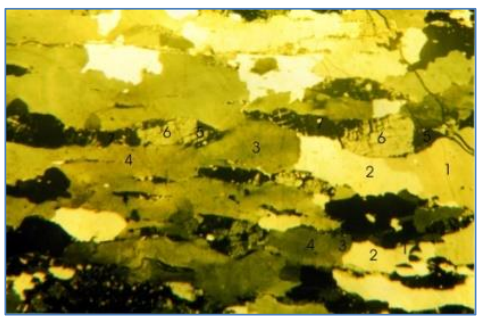

b

Рис. 6. Структури розлінзування з диференціацісю речовини та розсланцювання генерації-3 на мезо- (a) та мікрорівнях (b), речовинно представлені білими різнозернистими гранітами та польовошпатовими кварцитами. Площина горизонтальна. Для а масштаб -кришечка фотоапарату; b - шліф, збільшення 25, ніколі схрещені. 1-7 - зонки різної будови й властивостей (1-4 - кварцу, 5-7 - плагіоклазів), які фіксують односпрямований послідовний ріст мінагрегатів та створюють сланцюватість і лінійність

Вік структур цього етапу ми прив'язуємо до часу 2,8 млрд років ${ }^{31,32}$. Вони є січними до давніших утворень (рис. 3,7 ) та реліктами для дислокаційних структур наступних генерацій.

3 рис. 5 видно, що становлення дислокаційних структур генерації-3 відбувалося при порівняно незначній ротації напрямів дії тектонічних напруг. Але вони також формувалися щонайменше в три тектонічних імпульси, що зафіксовано в кількох максимумах мінеральної лінійності. Діаграма орієнтації оптичних осей кварцу з білих різнозернистих гранітоїдів за результатами замірів на федорівському столику (285 замірів) відображає аналогічні результати - три максимума. Один із них фіксує вертикально розміщені осі, другий - нахилені в діапазоні $30-50^{\circ}$, третій - майже горизонтально розміщені ${ }^{33}$. Зазначене свідчить, що досліджувані дислокаційні структури не $\epsilon$ накладеними на кристалічні породи, а структурно-речовинні перетворення, про які йдеться, відбувалися одночасно на всіх рівнях організації (від мікро- до макро-) геологічного середовища.

31 Кореляційна хроностратиграфічна схема раннього докембрію Українського щита / Ссипчук К.Ю., Бобров О.Б., Степанюк Л. М. та ін. УкрДГРІ. Київ, 2004.

32 Метаморфические и метасоматические комплексы Приазовья и Южного Донбасса / Горяйнов С.В., Коренев В.В., Аксенов С.В. и др. Харьков : Экограф, 2009. 303 c.

$3 \dot{3}$ Осьмачко Л.С. Типи, умови та етапи формування дислокаційної тектоніки Сорокинської зони та ії обрамлення (із позицій тектонофаціального аналізу) : дис. ... канд. геол. наук : 04.00 .04 «Геотектоніка». Київ, 2004. 189 с. 

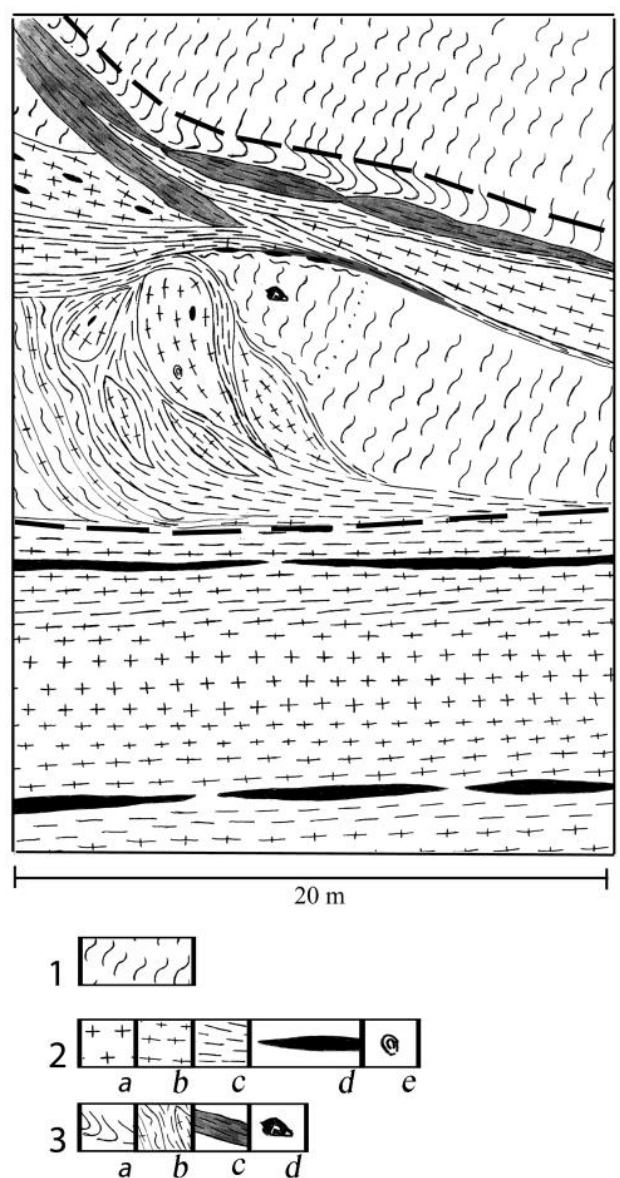

Рис. 7. Фрагмент контакту (окреслений пунктиром) в'язкорозломної зони етапу-3 з древнішими утвореннями. Площина горизонтальна. 1 - структури етапу-0-1; 2 a-е - композити в'язкорозломної зони етапу-3 складу: лейкократових гранітів (а-с - різний ступінь розсланцювання), польовошпатових кварцитів (d), реліктового (e); 3 a-d - складові контактної зони:

а - структури підвороту смугастості-0-1, b - в різній мірі розліновані тіла етапів 0-3, с- реакційні утворення між структурами етапів 0-1 та 3 (озалізнені гранітогнейси), d - лінзовидні тіла пегматоїдів 
На рис. 8 наведені стереограми полюсів площин смугастості й сланцюватості (a) та занурення мінеральної лінійності (b) для дислокаційних структур генерації-4. Вони на мезо- та мікрорівнях представлені вторинною сингранітизаційною смугастістю, структурами мезорозлінзування, гнейсуватістю тощо. Зазначені структури формуються за Р-Т умов, близьких до солідусних ${ }^{34}$, за механізмами пластичної формозміни мінеральних зерен та їх агрегатів, синдеформаційної перекристалізації, трансляції, розлінзування та розшарування геологічного середовища (від рівня внутрішньозернового до рівня геологічних тіл).

Для структур цього етапу $є$ характерним субвертикальне падіння та субгоризонтальне розміщення мінеральної лінійності 3 кутом занурення на південь-південний схід 0-20 . На макрорівні структури цієї генерації виражені як в'язкі розломи. Їх формування ми прив'язуємо до часу 2,2-2,0 млрд років тому ${ }^{35,36,37}$. Така тектоніка порушує всі, без винятку, тектонічні структури попередніх етапів, підпорядковуючи їх власному структурному плану (рис. 2, 3). При цьому трансформується і мінеральний склад більш ранніх утворень, наближаючись до гранітоїдного.

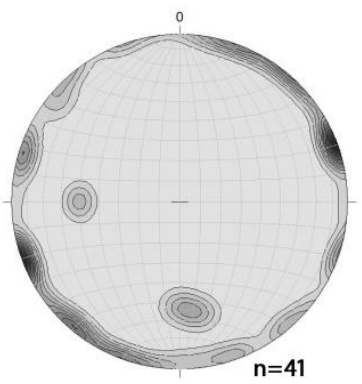

a

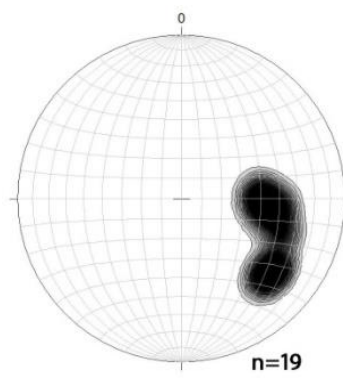

b

Рис. 8. Стереограми полюсів площин смугастості й сланцюватості

(a) та занурення лінійності за мінеральними агрегатами і осями складок (b) для червоних різнозернистих гранітоїдів (басейн р. Берестової). Інші позначення див. рис. 2

34 Лукієнко О.І., Кравченко Д.В., Сухорада А.В. Дислокаційна тектоніка та тектонофації докембрію Українського щита / ВПЦ. Київський університет, 2008. $280 \mathrm{c}$.

${ }^{5}$ Кореляційна хроностратиграфічна схема раннього докембрію Українського щита / Єсипчук К.Ю., Бобров О.Б., Степанюк Л. М. та ін. УкрДГРІ. Київ, 2004.

36 Метаморфические и метасоматические комплексы Приазовья и Южного Донбасса / Горяйнов С.В., Коренев В.В., Аксенов С.В. и др. Харьков : Экограф, $2009.303 \mathrm{c}$.

${ }_{37}$ Щербак Н.П., Артеменко Г.В., Лесная И.М. и др. Геохронология раннего докембрия Украинского щита (протерозой). Киев : Наук. думка, 2008. 240 с. 
3 рис. 8 видно, що становлення дислокаційних структур генерації-4 також відбувалося при ротації напрямів дії тектонічних напруг. Діаграма оріснтації оптичних осей кварцу за результатами замірів (245) на федорівському столику для гранітоїдів цієї генерації також демонструє чіткий подвійний максимум ${ }^{38}$.

На рис. 9 наведені стереограми полюсів площин смугастості й сланцюватості $\quad$ (a) та занурення мінеральної лінійності (b) для дислокаційних структур генерації-5. Вони на мезо- та мікрорівнях представлені вторинною гранітизаційною смугастістю, розлінзуванням, кліважем, будинажем та S-складками. Ці структури сформовані мінеральними парагенезисами, що відповідають епідот-амфіболітовій та зеленосланцьовій фаціям динамометаморфізму (рис. 10). Для них є характерним субвертикальне падіння та похиле розміщення мінеральної лінійності з кутом занурення на північ-північний захід 0-20 (рис. 2, 5, 9).

Формування структур цієї генерації відбувалося щонайменше у два етапи, про що свідчить два максимума концентрації лінійних структурних елементів. Остаточне становлення структур генерації-5 ми прив'язуємо до часу $1,9-1,7$ млрд років тому ${ }^{39,40,41}$. Вони розвинені на досліджуваній території сіткоподібно.

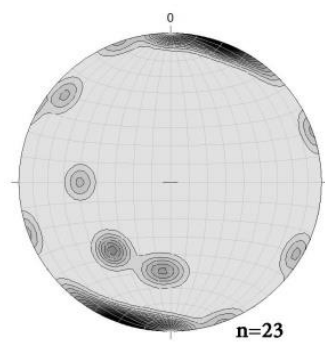

a

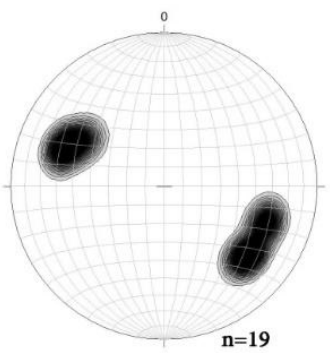

b

Рис. 9. Стереограми полюсів площин смугастості й сланцюватості

(a) та занурення лінійності за мінеральними агрегатами і осями складок (b) для геологічних тіл сформованих мінеральними парагенезисами зеленосланцевої фації метаморфізму (басейн р. Берестової). Інші позначення див. вище

38 Осьмачко Л.С. Типи, умови та етапи формування дислокаційної тектоніки Сорокинської зони та ії обрамлення (із позицій тектонофаціального аналізу) : дис. ... канд. геол. наук : 04.00.04 «Геотектоніка». Київ, 2004. 189 с.

${ }_{9}$ Кореляційна хроностратиграфічна схема раннього докембрію Українського щита / Єсипчук К.Ю., Бобров О.Б., Степанюк Л.М. та ін. УкрДГРІ. Київ, 2004.

40 Метаморфические и метасоматические комплексы Приазовья и Южного Донбасса / Горяйнов С.В., Коренев В.В., Аксенов С.В. и др. Харьков : Экограф, 2009. 303 c.

$4 \mathrm{i}$ Щербак Н.П., Артеменко Г.В., Лесная И.М. и др. Геохронология раннего докембрия Украинского щита (протерозой). Киев : Наук. думка, 2008. 240 с. 


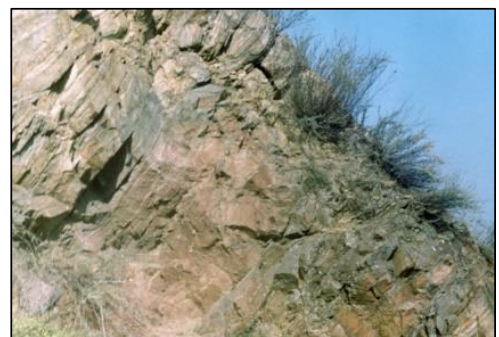

a

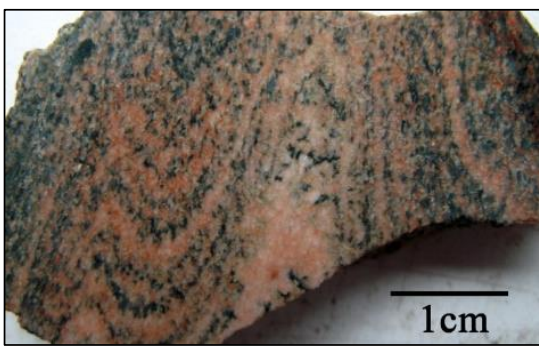

b

Рис. 10. Фрагмент в'язкого розлому етапу-5, де згідно перемежовуються більш давні тіла та вторинна смугастість

гранітного складу і сформована агрегатами мінералів зеленосланцевої фації метаморфізму. а - загальний вигляд (зріз близький до вертикального, експозиція південно-західна); b - деталь (зріз у вертикальній площині). Шарніри цих складочок

та подовжені мінагрегати формують похилу лінійність, що показана на рис. 9 b. (басейн р. Берестової)

На рис. 11 наведені стереограми полюсів площин структур генерації-6, які представлені крихко-кліважними зонками. Вони сформовані за низьких Р-Т умов граніт-метаморфічного середовища та не супроводжуються динамометаморфічними змінами порід.

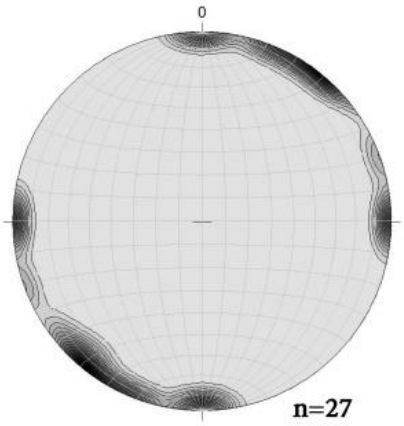

Рис. 11. Стереограма полюсів площин кліважу, що розвинений по більшості дислокаційних утворень попередніх генерацій (басейн р. Берестової). Інші позначення див. вище

\section{2. Ядро Мангуського синклінорію}

\section{як закономірна його складова частина}

Наведені вище факти свідчать, що всі без винятку породні різновиди геологічних тіл в об'ємі, що відповідає західному крилу Мангуського 
синклінорію формувалися завдяки неодноразовим структурно-речовинним трансформаціям за тектонічних умов здвигу/ротації при регресивній зміні P-Т параметрів геологічного середовища. Відштовхуючись від положення, що геологічні макросистеми є множинами більш елементарних об'єктів, які перебувають у певних відношеннях і зв'язках між собою ${ }^{42,43,44}$, а прояв дислокаційних перетворень на макрорівні відображується на мікрорівні та навпаки, а також від наведених вище та нижче даних щодо структурноречовинної організації «ядра» Мангуського синклінорію, можна стверджувати наступне. «Ядро» Мангуського синклінорію й рудні тіла в його межах створювалися за тектонічних умов, за яких відбувалося i становлення досліджуваного крила синклінорію. Зазначені дані систематизовані відповідно до супідрядності геологічних структур, розпочинаючи з макрорівня (пункт 1) структурно-речовинної організації об'єкту і закінчуючи мікрорівнем (пункт 8).

За даними робіт ${ }^{45,46,4}$, «ядро» - це антиклінальний перегин, що ускладнює осьову частину синклінорію (Мангуської структури).

1. «Ядро синклінорію» (антикліналь) $є$ каплеподібним у плані макротілом із субмеридіонально розміщеною видимою довгою віссю. «Ядро» в плані завширшки сягає 10 км, у довжину до 25 км та має круті падіння крил - від 60 до $87^{\circ}$. Загалом за морфологією це тіло конформне обрисам синклінорію. «Ядро» й інші подібні за конфігурацією й елементами залягання лінзоподібні макротіла, які розміщені одне від одного на відстані 5-10 км, є сегментами субмеридіонально розташованого ланцюжка таких тіл (рис. 12). Ланцюжок просторово близький до осьової поверхні синклінорію.

42 Лукієнко О.І., Кравченко Д.В., Сухорада А.В. Дислокаційна тектоніка та тектонофації докембрію Українського щита / ВПЦ. Київський університет, 2008. $280 \mathrm{c}$.

${ }^{43}$ Паталаха Е.И., Лукиенко А.И., Гончар В.В. Тектонические потоки как основа понимания геологических структур. Киев : Феникс, 1995. 159 с.

${ }^{44}$ Горяинов П.М., Иванюк Г.Ю. Самоорганизация минеральных систем. Москва: Геокарт, 2001. 315 с.

45 Державна геологічна карта України. М-б 1:200 000. Центральноукраїнська серія. L-37-VIII (Маріуполь), L-37-IX (Таганрог) / Б.В. Бородиня, І.Л. Князькова, Т.Я. Іваненко та ін. Київ : Державна служба геології та надр України, УкрДГРІ, КП «Південукргеологія», 2012.

46 Железисто-кремнистая формация докембрия Мариупольского рудного поля / Отв. ред. Ю.Ю. Юрк. Авт.:Зарицкий А.И., Каныгин Л.И., Кирикилица С.И., Лебедев Ю.С., Левенштейн М.Л., Лучинская Г.Л., Полуновский Р.М., Сухицкая Н.Я., Харагезов М.К. Москва : Недра, 1974. 150с.

Железисто-кремнистые формации Украинского Щита. Том I. Отв.ред Н.П. Семененко. Ладиева В.Д., Бордунов И.Н., Бойко В.Л., Кутин В.В., Струева О.М., Рябоконь С.М., Половко Н.И. и др. Київ : Наук. думка, 1978. 327 с. 


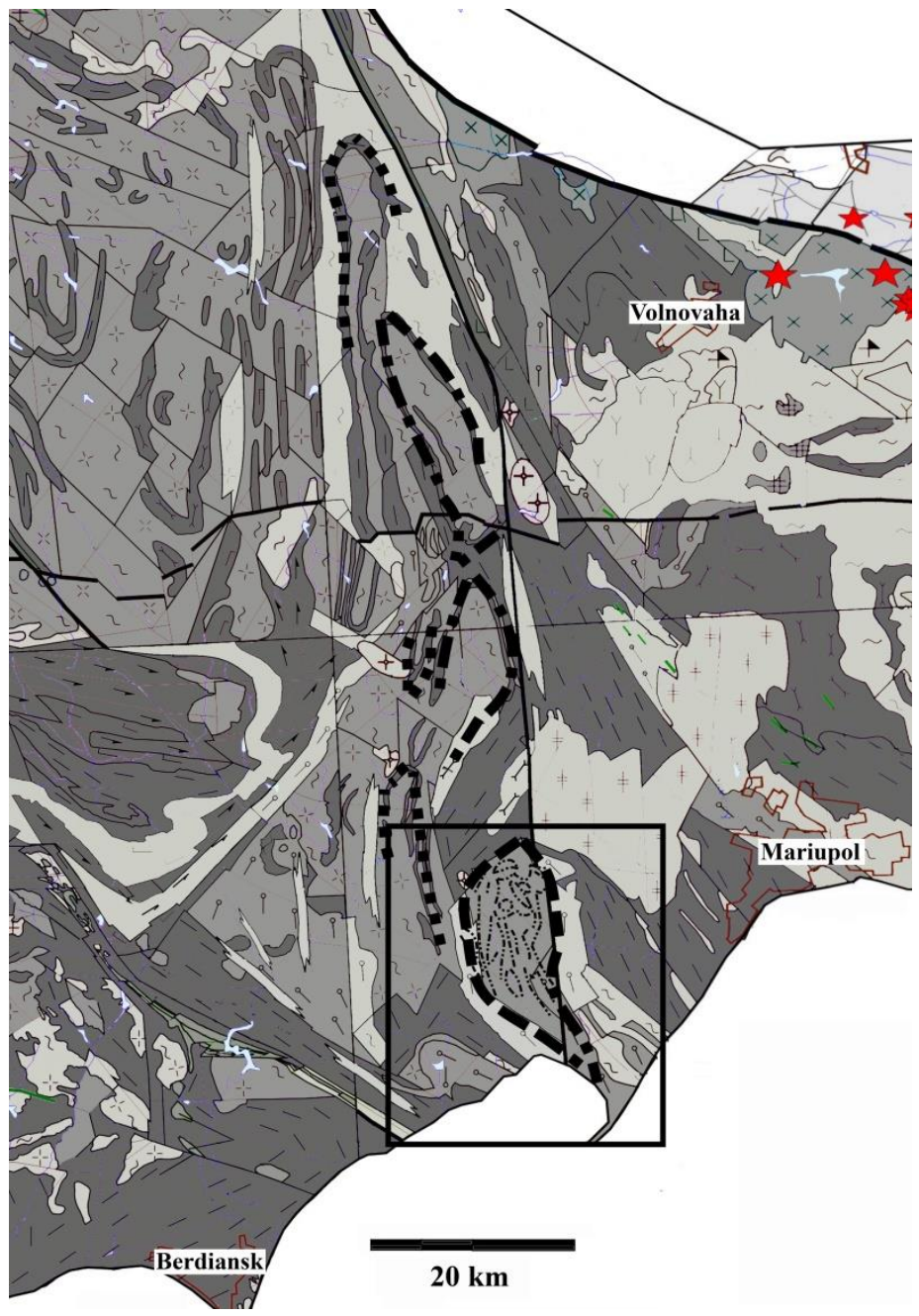

Рис. 12. «Ядро» Мангуського синклінорію (окреслене пунктиром в прямокутному контурі) у складі субмеридіонального ланцюжка лінзоподібних макротіл. На основі ${ }^{48,49}$ доповненнями автора. Інші позначення див. рис. 1

${ }^{48}$ Кічурчак В.М., Пігулевський П.Г. Геолого-формаційна карта південно-східної частини УЩ. М 1:500 000. МОН природного середовища України. ДГП «УкрГеофізика». ДГЕ «ДніпроГеофізика». Київ. 2003 р. 
За межами ланцюжка в об'ємі синклінорію простежуються подібні ланцюжки дещо менших за розмірами геологічних тіл зі схожими елементами залягання й співвідношеннями $\boldsymbol{a}: \boldsymbol{c}$.

Коротко охарактеризована макробудова «ядра» Мангуського синклінорію та його оточення свідчить, що цей фрагмент кристалічного фундаменту $\epsilon$ впорядкованою макроструктурою розлінзування та будинажу, формування якої можливе за неодноразових деформацій здвигу докембрійського фундаменту в супроводі розосередження та прокручування окремих його складників. Більші розміри макротілсегментів осьового ланцюжка Мангуської структури, порівняно подібних тіл інших ланцюжків може бути ознакою порівняно меншої інтенсивності тектоно-метаморфічних трансформацій в осьовій частині синклінорію щодо крайових його частин.

2. Внутрішній структурний малюнок «ядра» Мангуського синклінорію лускувато-центробіжний, який сформований відповідним просторовим розміщенням й морфологією геологічних тіл, що його утворюють (рис. 13). Структурний малюнок цього рівня організації підпорядкований як каплеподібному контуру «ядра», так i загальному, для центральної частини мегаблоку, субмеридіональному структурному плану. В межах внутрішнього структурного малюнку «ядра» виділяються субкільцеві (серпо- й еліпсоподібні), гачко- та пласто-лінзоподібні тіла. Діаметр субкільцевих тіл варіюється від 1 до 5 км, a:c сягає 3-5; потужності пласто-лінзоподібних тіл - від 0,5 до 1,5 км при довжині 8-10 км, тобто їх $\boldsymbol{a : c}$ в горизонтальній площині сягає 10. Як серед пластоподібних, так і субкільцевих тіл є складені і гранітоїдами, i метаморфічними породами. Геологічні тіла, що сформовані метаморфічними породами, мають максимальні потужності в осьових частинах й мінімальні на крилах ${ }^{50,51}$. Це Північна, Дем’янівська, Первомайська, Дзержинська та інші складки (рис. 13).

49 Державна геологічна карта України. М-б 1:200 000. Центральноукраїнська серія. L-37-VIII (Маріуполь), L-37-IX (Таганрог) / Б.В. Бородиня, І.Л. Князькова, Т.Я. Іваненко та ін. Київ : Держ. служба геології та надр України, УкрДГРІ, КП «Південукргеологія», 2012.

50 Железисто-кремнистая формация докембрия Мариупольского рудного поля / Отв. ред. Ю.Ю. Юрк. Авт.: Зарицкий А.И., Каныгин Л.И., Кирикилица С.И., Лебедев Ю.С., Левенштейн М.Л., Лучинская Г.Л., Полуновский Р.М., Сухицкая Н.Я., Харагезов М.К. Москва : Недра, 1974. 150 с.

1 Железисто-кремнистые формации Украинского Щита. Том I / Отв. ред Н.П. Семененко. Ладиева В.Д., Бордунов И.Н., Бойко В.Л., Кутин В.В., Струева О.М., Рябоконь С.М., Половко Н.И. и др. Київ : Наук. думка, 1978. 327 с. 


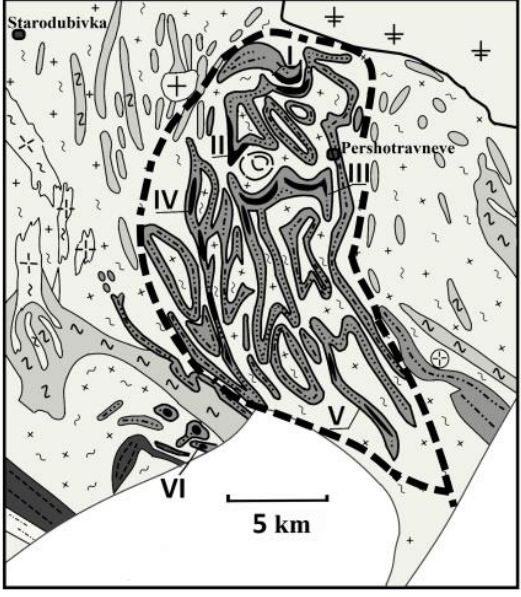

a
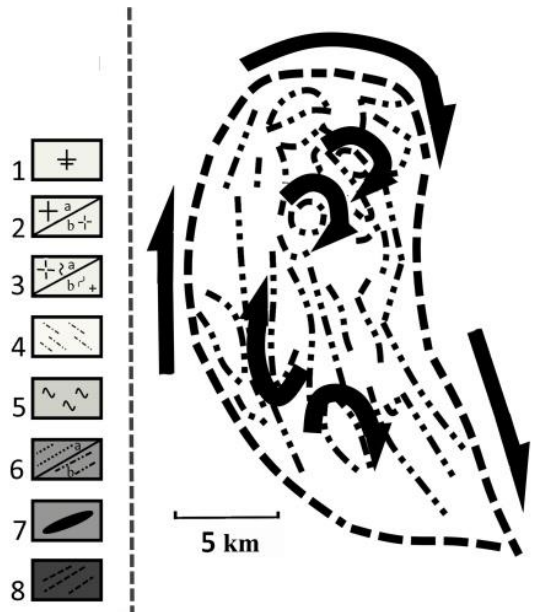

b

Рис. 13. Будова «ядра» (окреслене пунктиром) Мангуського синклінорію за даними ${ }^{52,53}$. а - карта, рамка якої відповідає прямокутному контуру на рис. 12 ; b - схематизовані конфігурація й внутрішня центробіжно-лускувата будова "ядра" та реставровані напрямки переміщень на час становлення даної структури.

1 - сублужні граніти; 2 - граніти (a) та пегматити (b) мезопротерозою; 3 - плагіограніт-мігматити (a) та гранітмігматити (b) палеопротерозою; 4 - породи осипенківської серії; 5 - каратюцька світа (гнейси графіт-біотитові 3 гранатом, гнейси

і кристалічні сланці) палеопротерозою; 6 - сачкінська (дем'янівська) світа, а - кварцити, гнейси глиноземисті, біотитові графіт- і гранатвмісні, кристалічні сланці, b - піроксенвмісні кристалічні сланці і амфіболіти; 7 - залізисто-кремнисті породи;

8 - темрюцька світа (кварцити, гнейси високоглиноземисті, гранатові й амфіболові, кристалічні сланці магнетитвмісні і амфібол-піроксенові). Рудні структури: I - Північна, II - Дем'янівська, III - Первомайська, IV - VI - інші

52 Полуновский Р.М. Литолого-петрографические особенности, стратиграфия и металлогения гнейсовой серии Центрального Приазовья : автореф. дис. канд. геол.-мин. наук : 04.00.01 / ІГФМАНУ. Київ, 1970. 24 с.

Геологическая карта докембрия восточной части Украинского щита (территория Большого Кривого Рога) и палеозойских (допермских) образований северного склона щита и зоны сочленения с Донбассом. 1: 200000 / Сост. Ю.Б. Бабков, А.Г. Батурина, М.Н. Доброхотов и др. Под ред. М.Н. Доброхотова, Ю.Ю. Юрка. Мин-во геологии УССР, Киев. 1972. 12 л. 
Всі вони мають подібні розрізи за простяганням та різко відмінні вхрест простягання «ядра», також містять згідні тіла залізистих кварцитів $^{54,55,56}$. Занурення шарнірів складок, як круте, так і похиле на північ та південь, подібне до розміщення мінеральної лінійності, що охарактеризовано вище.

Більша частина аномалій U-Th-природи «ядра» Мангуського синклінорію зосереджена в Первомайській складц ${ }^{16}$ гачкоподібної форми. Падіння пачок порід на крилах складки круте (до $80^{\circ}$ ), в замковій частині - центробіжне ${ }^{57,58}$. Більшість рудопроявів приурочена до іiі північно-східної частини, яка ускладнена складчастістю більш високих порядків. Ця частина складки сформована амфіболопіроксено-плагіоклазовими гнейсами, залізистими кристалічними сланцями кварцево-гранато-піроксенового складу, графітвмістними гнейсами i карбонатними породами. Потужності рудних тіл зіставляють $0,2-0,6 \mathrm{~m}^{59,60}$, які переважно знаходяться в мігматитах та гранітоїдах, рідше на їх контактах із метаморфічними породами.

Відповідно ${ }^{61,62,63}$ формування вищеописаної будови «ядра» Мангуського синклінорію можливе за тотального залучення первинної кристалічної основи до неодноразових деформацій здвигу-розтягу

54 Железисто-кремнистая формация докембрия Мариупольского рудного поля / Отв. ред. Ю.Ю. Юрк. Авт.:Зарицкий А.И., Каныгин Л.И., Кирикилица С.И., Лебедев Ю.С., Левенштейн М.Л., Лучинская Г.Л., Полуновский Р.М., Сухицкая Н.Я., Харагезов М.К. Москва : Недра, 1974. 150 с.

55 Железисто-кремнистые формации Украинского Щита. Том I. Отв.ред Н.П. Семененко. Ладиева В.Д., Бордунов И.Н., Бойко В.Л., Кутин В.В., Струева О.М., Рябоконь С.М., Половко Н.И. и др. Київ : Наук. думка, 1978. 327 с.

56 Державна геологічна карта України. М-б 1:200 000. Центральноукраїнська серія. L-37-VIII (Маріуполь), L-37-IX (Таганрог) / Б.В. Бородиня, І.Л. Князькова, Т.Я. Іваненко та ін. Київ : Держ. служба геології та надр України, УкрДГРІ, КП «Південукргеологія», 2012.

57 Железисто-кремнистая формация докембрия Мариупольского рудного поля / Отв. ред. Ю.Ю. Юрк. Авт.:Зарицкий А.И., Каныгин Л.И., Кирикилица С.И., Лебедев Ю.С., Левенштейн М.Л., Лучинская Г.Л., Полуновский Р.М., Сухицкая Н.Я., Харагезов М.К. Москва : Недра, 1974. 150с.

58 Державна геологічна карта України. М-б 1:200 000. Центральноукраїнська серія. L-37-VIII (Маріуполь), L-37-IX (Таганрог) / Б.В. Бородиня, І.Л. Князькова, Т.Я. Іваненко та ін. Київ : Держ. служба геології та надр України, УкрДГРІ, КП «Південукргеологія», 2012.

59 Державна геологічна карта України. М-б 1:200 000. Центральноукраїнська серія. L-37-VIII (Маріуполь), L-37-IX (Таганрог) / Б.В. Бородиня, І.Л. Князькова, Т.Я. Іваненко та ін. Київ : Держ. служба геології та надр України, УкрДГРІ, КП «Південукргеологія», 2012.

60 Закономерности образования и размещения урановых месторождений Украины / Редакционная коллегия: Я.Н. Белевцев, В.Ю. Фоменко, Б.И. Горошников и др. Авторы: М.Я. Абдулина, Л.И. Авдеева, Д.Е. Айзенберг и др. Киев : АН УССР, МИНГЕО СССР, 1968. 763 с.

${ }^{61}$ Паталаха Е.И., Лукиенко А.И., Гончар В.В. Тектонические потоки как основа понимания геологических структур. Киев : Феникс, 1995. 159 с.

62 Родыгин А.И. Признаки направления смещения при деформации сдвига. Томск : Изд-во Томского ун-та, 1991.99 с.

63 Слензак О.И. Локальные структуры зон напряжений докембрия. Київ : Наук. думка, 1984. $102 \mathrm{c}$. 
й прокручування окремих його складників на цьому рівні організації геологічного середовища. Тобто це вторинна стратифікація (структурна та речовинна перебудова), лінеаризація граніто-метаморфічного середовища, яка зумовлена зазначеними тектонічними факторами й виражена як перешарування дуже сплющених, витягнутих та зміщених усіх без винятку за складом геологічних тіл. Отже, складки крайової частини «ядра» відповідають приздвиговим лінійним складкам та S-складкам, складки внутрішньої його частини - внутрішньобудинним складкам волочіння «завертышам» ${ }^{64,65}$. При цьому, спираючись на дані С.В. Горяйнова зі співавторами ${ }^{66}$, складки 3 вертикально розміщеними шарнірами ми ототожнюємо 3 дислокаційними структурами генерації-3 ( 2,8 млрд років тому), складки 3 шарнірами, що похило занурюються на південь - зі структурами генерації-4 ( 2,0 млрд років тому), з шарнірами, що похило занурюються на північ, - із дислокаційними структурами генерації-5 ( 1,8 млрд років тому).

3. Геологічні тіла мезорівня (на рівні пачок порід), як нерудні, так і $\mathrm{Fe}-$ та U-вмісні, що формують вище означені складки, згідно перемежовуються та мають однакові елементи залягання. Зокрема, це пачки: амфіболо-піроксено-плагіоклазових гнейсів, залізистих кристалічних сланців кварцево-гранато-піроксенового складу, піроксеномагнетитових кварцитів; графітвмістних гнейсів і карбонатних порід ${ }^{67,68}$. Співвідношення а:c таких пачок-складників, морфологія й елементи залягання аналогічні й повністю узгоджені 3 такими атрибутами складчастих форм вищих рівнів організації (рис. 13).

Коротко окреслена будова рудовмісних структур та рудних тіл (в пунктах 2, 3) $є$ свідченням їх становлення під дією здвигових трансформації, що провокують ротацію товщ й перерозподіл рудної речовини з їі перевідкладенням в обрамленнях тіл скручування ${ }^{69,70}$.

4. Всі - як рудні, так і нерудні - геологічні тіла мезорівня (які формують «ядро» синклінорію) структурно-текстурно неоднорідні, що

64 Родыгин А.И. Признаки направления смещения при деформации сдвига. Томск : Изд-во Томского ун-та, 1991.99 с.

${ }^{65}$ Слензак О.И. Локальные структуры зон напряжений докембрия. Киев : Наук. думка, 1984. $102 \mathrm{c}$.

66 Метаморфические и метасоматические комплексы Приазовья и Южного Донбасса / Горяйнов С.В., Коренев В.В., Аксенов С.В. и др. Харьков : Экограф, 2009. $303 \mathrm{c}$.

67 Закономерности образования и размещения урановых месторождений Украины / Редакционная коллегия: Я.Н. Белевцев, В.Ю. Фоменко, Б.И. Горошников и др. Авторы: М.Я. Абдулина, Л.И. Авдеева, Д.Е. Айзенберг и др. Киев: АН УССР, МИНГЕО СССР, $1968.763 \mathrm{c}$.

68 Железисто-кремнистая формация докембрия Мариупольского рудного поля / Отв. ред. Ю.Ю. Юрк. Авт.:Зарицкий А.И., Каныгин Л.И., Кирикилица С.И., Лебедев Ю.С., Левенштейн М.Л., Лучинская Г.Л., Полуновский Р.М., Сухицкая Н.Я., Харагезов М.К. Москва : Недра, 1974. 150 с.

69 Родыгин А.И. Признаки направления смещения при деформации сдвига. Томск : Изд-во Томского ун-та, 1991.99 с.

${ }^{70}$ Слензак О.И. Локальные структуры зон напряжений докембрия. Київ : Наук. думка, 1984. 102 с. 
виражено як розлінзована смугастість та сланцюватість. Смугастість зумовлена як варіаціями мінерального складу, так i зміною розмірностей мінеральних зерен; потужності таких смуг коливаються від кількох міліметрів до кількох сантиметрів. Зазначені варіації мінерального складу виражені закономірною зміною в розрізах геологічних тіл ряду мінеральних парагенезисів ${ }^{71,72,73}$.

Сланцюватість зумовлена односистемними подовженістю та розміщенням як рудних (магнетит) так і нерудних мінералів, також їх лінзоподібних агрегатів. Структури мінералів переважно кристалобластові. У площинах сланцюватості окремі мінерали й їх агрегати мають $\sigma$-подібні форми. Смугастість і сланцюватість всіх мезотіл взаємоузгоджені як між собою, так і морфологією геологічних тіл. При цьому просторове розміщення смугастості й сланцюватості U- й Fe-рудних тіл відповідає розміщенню рудовмісних тіл та їх смугастості, як сланцево-гнейсового складу, так і гранітоїдного ${ }^{74}$.

Смугастість і сланцюватість та їхня тотальна взаємоузгодженість $\epsilon$ виразом процесу здвигу/розтягу на мікрорівні. На цьому рівні він реалізується завдяки синдеформаційній (компенсаційній) перекристалізації (дифузійний перерозподіл речовини) в напрямі відносно понижених деформаційних тисків ${ }^{75,76}$.

5. Для більшості різновидів порід досліджуваної частини Мангуської структури спостерігаються поступові переходи та при цьому чіткі межі. Зокрема між різновидами гранітоїдів, гранітоїдами і гнейсами, таконітами й ітабіритами тощо. Такі переходи виражені текстурно-структурно та речовинно. Зазначене свідчить про їх генетичний зв'язок, що підтверджується і на хімічному рівні ${ }^{77}$.

71 Горяинов П.М., Иванюк Г.Ю. Самоорганизация минеральных систем. Москва : Геокарт, 2001. 315 с.

2 Закономерности образования и размещения урановых месторождений Украины / Редакционная коллегия: Я.Н. Белевцев, В.Ю. Фоменко, Б.И. Горошников и др. Авторы: М.Я. Абдулина, Л.И. Авдеева, Д.Е. Айзенберг и др. Киев : АН УССР, МИНГЕО СССР, 1968. 763 с.

73 Железисто-кремнистые формации Украинского Щита. Том I / Отв. ред Н.П. Семененко. Ладиева В.Д., Бордунов И.Н., Бойко В.Л., Кутин В.В., Струева О.М., Рябоконь С.М., Половко Н.И. и др. Київ : Наук. думка, 1978. 327 с.

74 Железисто-кремнистая формация докембрия Мариупольского рудного поля / Отв. ред. Ю.Ю. Юрк. Авт.: Зарицкий А.И., Каныгин Л.И., Кирикилица С.И., Лебедев Ю.С., Левенштейн М.Л., Лучинская Г.Л., Полуновский Р.М., Сухицкая Н.Я, Харагезов М.К. Москва : Недра, 1974. 150 с.

75 Паталаха Е.И., Лукиенко А.И., Гончар В.В. Тектонические потоки как основа понимания геологических структур. Киев : Феникс, 1995. 159 с.

${ }^{76}$ Слензак О.И. Локальные структуры зон напряжений докембрия. Киев : Наук. думка, 1984. 102 с.

77 Железисто-кремнистые формации Украинского Щита. Том I / Отв. ред. Н.П. Семененко. Ладиева В.Д., Бордунов И.Н., Бойко В.Л., Кутин В.В., Струева О.М., Рябоконь С.М., Половко Н.И. и др. Киев : Наук. думка, 1978. 327 с. 
Залізистим кварцитам притаманна закономірна зміна хімізму від центру (найбільш відкриті складки) до периферії (найбільш зжаті складки) окремих мінералів, їх агрегатів (смуг), геологічних тіл та навіть родовищ. Така закономірність за своєю геохімічною направленістю вирізняється постійністю і не залежить від положення залізистих кварцитів у розрізі ${ }^{78,79}$.

Оскільки Fе-вмісні тіла та їх внутрішня структурно-текстурна впорядкованість конформні цим самим атрибутам вмісних, а разом вони формують структурний малюнок, що створюється в умовах здвигу/ротації, зазначені зміни хімізму також $\epsilon$ результатом цих тектонічних дій.

6. Ступінь метаморфізму залізисто-кремнистих утворень району визначена як гранулітова ${ }^{80}$. Температури метаморфізму сягали 700-800 ${ }^{\circ} \mathrm{C}$, інтервал тиску - 7-10 кбар. Температури накладеного ретроградного метаморфізму - $500-800^{\circ}$ С встановлені із перекристалізованих амфіболових і амфібол-клінопіроксенових залізистих кварцитів. Останні формувалися в умовах протерозойського складкоутворення за рахунок смугастих піроксен-магнетитових ітабіритів ${ }^{81}$.

Оскільки мінеральні асоціації, за якими визначалися Р-Т умови, формують дислокаційні структури - лінійність, сланцюватість, смугастість й інші, встановлені значення тисків i температур $\epsilon$ параметрами дислокаційних перетворень.

7. Для геологічних тіл Мангуської структури відомі кілька цифр віку - 2,7 та 2,1 млрд років (ендербіти і чарнокіти токмацького й мангуського комплексів), 2,0 (плагіограніти каратюцького комплексу й гранодіорити максимівської асоціації) та 1,8 млрд років (граніти мікроклінові кам'яномогильного комплексу $)^{82,83}$. Для геологічних тіл інших макроструктур Приазов'я також відомі подібні цифри ізотопного

78 Горяинов П.М., Иванюк Г.Ю. Самоорганизация минеральных систем. Москва : Геокарт, 2001.315 с.

79 Железисто-кремнистая формация докембрия Мариупольского рудного поля / Отв. ред. Ю.Ю. Юрк. Авт.:Зарицкий А.И., Каныгин Л.И., Кирикилица С.И., Лебедев Ю.С., Левенштейн М.Л., Лучинская Г.Л., Полуновский Р.М., Сухицкая Н.Я., Харагезов М.К. Москва : Недра, 1974. 150 с.

80 Державна геологічна карта України. М-б 1:200 000. Центральноукраїнська серія. L-37-VIII (Маріуполь), L-37-IX (Таганрог) / Б.В. Бородиня, І.Л. Князькова, Т.Я. Іваненко та ін. Київ: Держ. служба геології та надр України, УкрДГРІ, КП «Південукргеологія», 2012.

${ }^{81}$ Железисто-кремнистые формации Украинского Щита. Том I / Отв. ред. Н.П. Семененко. Ладиева В.Д., Бордунов И.Н., Бойко В.Л., Кутин В.В., Струева О.М., Рябоконь С.М., Половко Н.И. и др. Киев : Наук. думка, 1978. 327 с.

82 Кореляційна хроностратиграфічна схема раннього докембрію Українського щита / Єсипчук К.Ю., Бобров О.Б., Степанюк Л. М. та ін. УкрДГРІ. Київ, 2004.

${ }_{83}$ Щербак Н.П., Артеменко Г.В., Лесная И.М. и др. Геохронология раннего докембрия Украинского щита (протерозой). Киев : Наук. думка, 2008. 240 с. 
віку $^{84,85}$. Метаморфічні утворення центральноприазовської серії в «Кореляційній схемі» ${ }^{86}$ розміщені на рівні 2,8-2,6 млрд років.

Зазначені типи порід й інші містять кілька генерацій (різновидів) акцесорних й породоутворювальних мінералів. Зокрема, ромбічні піроксени представлені цілим рядом від енстатиту до еуліта; моноклінних піроксенів - до двох різновидів, плагіоклазів - 3 генерації, амфіболів - 3, гранатів - 3, біотитів - 3, кварцу -3 , магнетиту -3 . Плагіоклази при цьому зональні, полісинтетично здвійниковані. Двійники часто виклинюються та мають хвилясте згасання ${ }^{87,88}$

Кількість генерацій породоутворювальних й акцесорних мінералів та їх неоднорідна будова, кілька цифр віку та значень Р-Т засвідчують кількоетапність, імпульсність формування досліджуваного об'єкта. Адже певний різновид породоутворювального і акцесорного мінералу є кінцевим продуктом відповідного мінералоутворювального процесу - результатом особливостей хімізму, симетрії геологічного об'єму, насиченості компонентами росту, $P T$-умов геологічного середовища, тощо на момент його формування. Оскільки кристалічні породи Мангуської структури мають ознаки синтектонічних утворень (див. вище), сформованих за високих Р-Т значень та є закономірною складовою частиною структурного малюнку території, кожен із вікових і мінеральних різновидів цих порід $€$ результатом прояву одного з тектонічних імпульсів.

8. У разі уранової і уран-торієвої природи радіоактивності рівновага зміщена в сторону надлишку урану. Тип зруденіння вкраплений, вкрапленики зазвичай розміщені ланцюжкоподібно та містяться на межах зон доростання мінералів. Рудні мінерали представлені уранінітом та урановою черню ${ }^{89,90}$.

84 Геолого-геоэлектрическая модель Орехово-Павлоградской шовной зоны Украинского щита / Азаров Н.Я., Анциферов А.В., Шеремет Е.М., Глевасский Е.Б. и др. Киев : Наук. думка, 2005. 190 с.

${ }^{85}$ Щербак Н.П., Артеменко Г.В., Лесная И.М. и др. Геохронология раннего докембрия Украинского щита (протерозой). Киев : Наук. думка, 2008. 240 с.

${ }^{86}$ Кореляційна хроностратиграфічна схема раннього докембрію Українського щита / Єсипчук К.Ю., Бобров О.Б., Степанюк Л. М. та ін. УкрДГРІ. Київ, 2004.

87 Железисто-кремнистые формации Украинского Щита. Том I / Отв. ред. Н.П. Семененко. Ладиева В.Д., Бордунов И.Н., Бойко В.Л., Кутин В.В., Струева О.М., Рябоконь С.М., Половко Н.И. и др. Киев : Наук. думка, 1978. 327 с.

88 Железисто-кремнистая формация докембрия Мариупольского рудного поля / Отв. ред. Ю.Ю. Юрк. Авт.:Зарицкий А.И., Каныгин Л.И., Кирикилица С.И., Лебедев Ю.С., Левенштейн М.Л., Лучинская Г.Л., Полуновский Р.М., Сухицкая Н.Я., Харагезов М.К. Москва : Недра, 1974. 150с.

89 Державна геологічна карта України. М-б 1:200 000. Центральноукраїнська серія. L-37-VIII (Маріуполь), L-37-IX (Таганрог) / Б.В. Бородиня, І.Л. Князькова, Т.Я. Іваненко та ін. Київ : Держ. служба геології та надр України, УкрДГРІ, КП «Південукргеологія», 2012.

90 Закономерности образования и размещения урановых месторождений Украины / Редакционная коллегия: Я.Н. Белевцев, В.Ю. Фоменко, Б.И. Горошников и др. Авторы: М.Я. Абдулина, Л.И. Авдеева, Д.Е. Айзенберг и др. Киев : АН УССР, МИНГЕО СССР, 1968. 763 с. 
Тобто розміщення i форма виділень рудних мінералів підпорядковані структурному малюнку мікрорівня організації об'єкта.

\section{3. Узагальнення}

Поліхронний структурно-речовинний малюнок Мангуської дислокаційної макроструктури, від макро- до мікрорівня організації, підпорядкований субмеридіональним суттєво здвиговим зонам. Становлення останніх відбулося на 4-му й 5-му етапах структурноречовинних трансформацій кристалічної основи даної частини УЩ. Це 2 2,0 та 1,7 млрд років тому ${ }^{91,92}$.

«Ядро» Мангуської макроструктури (зони) разом 3 іншими каплеподібними макротілами формує закономірно впорядкований ланцюжок осьової частини зони. Внутрішня будова «ядра» центробіжнолуската як результат кількоетапних трансформацій здвигу/ротації кристалічної основи. Геологічні тіла, що складають центробіжно-лускатий малюнок «ядра» сформовані мезо- мікроструктурами - смугастістю та сланцюватістю, які згідні між собою для всіх петрографічних різновидів геологічних тіл. Останні сформовані кількома мінеральними генераціями, за якими відомо кілька цифр ізотопного віку. Рудні тіла досліджуваного фрагменту УЩ підпорядковані структурному малюнку об'єкта на всіх рівнях його організації. Тобто геологічні тіла-складові Мангуської структури, від макро- до мікрорівня, високовпорядковані, взаємоузгоджені, самоподібні на всіх рівнях організації, сформовані різко диференційованою речовиною. Зазначене свідчить про сумісне й взаємозалежне формування структурних форм i їх речовини. Таку досконалу будову досліджуваного об'єкта не можуть створити магматичні, осадові чи метасоматичні процеси, а лише тектонічний чинник,, а саме: структурно-речовинні перетворення, що реалізувались в динамічних умовах здвигу/ротації, які обгрунтовані вище. Тобто «ядро» Мангуської зони є iï закономірною складовою частиною, яке створювалося разом зі становленням всієї зони (в кілька етапів) і $є$ розлінованим й неодноразово структурно й речовинно трансформованим реліктом.

Окрім зазначеного, для встановлення взаємозв'язку зміни вмісту U й Th у гранітоїдах та супракрустальних утвореннях 3 етапами структурно-речовинних перетворень Приазовської частини УЩ ці дані згруповані на рис. 14. Під графіком показуємо просторово-часову еволюцію структурного малюнку досліджуваної частини кристалічного фундаменту, спираючись на дані, наведені в першій частині роботи. Із графіку слідує, що з кожним етапом зазначених перетворень вмісти

91 Кореляційна хроностратиграфічна схема раннього докембрію Українського щита / Єсипчук К.Ю., Бобров О.Б., Степанюк Л. М. та ін. УкрДГРІ. Київ, 2004.

92 Метаморфические и метасоматические комплексы Приазовья и Южного Донбасса / Горяйнов С.В., Коренев В.В., Аксенов С.В. и др. Харьков : Экограф, 2009. $303 \mathrm{c}$. 
$\mathrm{U}$ й Th у гранітоїдах збільшуються при зменшенні вмісту Th в супракрустальних утвореннях мегаблоку.

Всі вище систематизовані дані свідчать, що формування U-, Thрудних тіл Приазовського мегаблоку відбувалося синхронно 3 вмісними нерудними тілами, в одних і тих самих геолого-динамічних умовах, а саме, в декілька етапів структурно/речовинних перетворень кристалічної основи за здвигових деформацій. Тобто рудна речовина вилучалась із кристалічної основи, трансформувалась разом компонентами вмісних, переміщувалась й набувала нових речовинно/просторових форм, прилаштовуючись до Р-Т й кінематичних умов, провокованих тектонічними імпульсами, яких встановлено до восьми. За даними інших дослідників, відомо до 11.

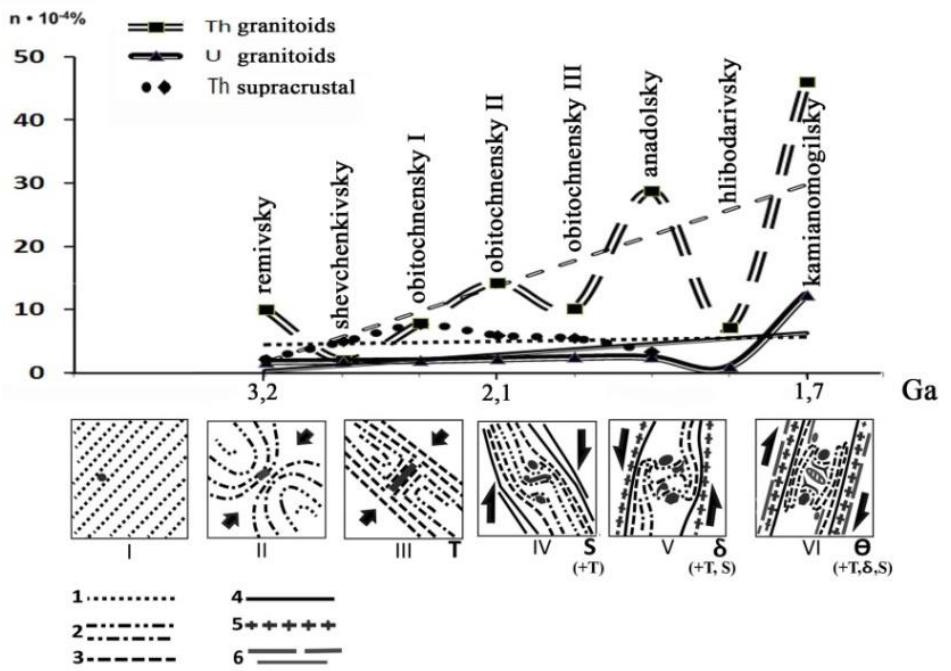

Рис. 14. Зміна вмісту U, Th в гранітоїдах та супракрустальних утвореннях Приазовського мегаблоку (за даними ${ }^{93}$ ) залежно від їх віку та етапу структурно-речовинних перетворень. Останні та становлення при цьому рудоперспективних структур показані в нижньому ряді. Стрілки - реставровані напрями зміщень, 1 - 6 - генерації площинних структур, T, S, $\Theta$ і $\delta$ - типи дислокаційних структур та сірі тіла (прямокутники, овали й неправильні) - рудні утворення на відповідні етапи розвитку структурного плану (I-VI). Над графіками - назви генерацій гранітоїдів; прямі лінії- тренди вмісту

${ }^{93}$ Перспективи розвитку торієвої сировинної бази ядерної енергетики України / В.Г. Верховцев, А.В. Кузьмін, М.О. Ярощук, О.О.Крамар, Є.Б. Краснов, Г.В. Лисиченко, Л.С. Осьмачко, К.Г. Сущук та ін. Київ : Наукова думка, 2017. 269 с. 


\section{ВИСНОВКИ}

Становлення структурного плану центральної частини Приазовського мегаблоку Українського щита відбувалося в кілька етапів структурно-речовинних перетворень кристалічної основи за суттєво здвигових трансформацій при змінах напрямів тектонічних напруг та Р-Т умов прояву. Виділено вісім таких етапів. Структурноречовинні перетворення фундаменту перших п'яти етапів реалізувалися в діапазоні Р-Т умов від гранулітової до епідот-амфіболітової зеленосланцевої фації. 3 кожним таким етапом формувалися структурно-речовинні новоутворення, які, накладаючись одні на інші, створили гібридну будову кристалічного фундаменту. Найбільш тотально проявилися структурні й речовинні трансформації четвертого та п'ятого із виділених етапів із формуванням субмеридіональної суттєво здвигової Мангуської зони. Перетворення більш пізніх етапів відбувалися переважно в холодних умовах та значно не змінили вже сформованого структурного плану, а лише посилили його структурну та речовинну зональність. Як результат відзначених структурноречовиних трансформацій, Мангуська міжблокова зона Приазовського мегаблоку $є$ ієрархічною, самоподібною на всіх рівнях організації, високоузгодженою дислокаційною структурою.

«Ядро» Мангуської зони є ії закономірною складовою частиною, що створювалося разом зі становленням всієї зони.

Докембрійські дислокаційні структури всіх генерацій, від макро- до мікрорівня впорядкування, формують суттєво здвигові структурні малюнки.

Досліджувані рудні тіла (зокрема U-, Th- вмісні) всіх ієрархічних рівнів $є$ закономірними складниками таких структурних малюнків на відповідних рівнях організації, а саме: рудоносні тіла мають морфологію й елементи залягання, аналогічні вмісним геологічним тілам. Такі ознаки рудних й вмісних тіл, як геохімічні спеціалізації, кількість генерацій малих структурних форм, рудних й породоутворювальних мінералів, є близькими.

Виведена схематизована модель багатоетапного становлення докембрійського структурно-речовинного малюнку центральної частини Приазовського мегаблоку та відображені структурні позиції рудних тіл у цьому малюнку.

Вміст U й Тh зростає 3 кожною генерацією структурно-речовинних новоутворень (від палеоархейських до палеопротерозойських), а у вміщуючих породах, навпаки, зменшується. Найбільш суттєві концентрації U й Th приурочені до палеопротерозойського структурноречовинного малюнку, який сформувався на п'ятому етапі еволюції кристалічного фундаменту.

Отже, рудні тіла пройшли ту саму історію формування - сформовані завдяки тому ж багатоактному тектонічному процесу (здвигу/ротації), 
що й породоутворювальні мінерали, агрегати та тіла вмісних. U-, Th-рудні тіла $\epsilon$ високовпорядкованими тектоно-метаморфогенними утвореннями (приздвиговими утворами). Тому вони займають закономірні структурні комірки в протерозойському структурному плані УЩ - T-, S-, Ө-позиції, що маркують приздвигові тіні тиску. Зазначене вважаємо провідним пошуковим критерієм.

\section{АНОТАЦІЯ}

Мангуська міжблокова зона як результат багатоетапних петроструктурних перетворень $\epsilon$ ієрархічною, самоподібною й високоузгодженою (для всіх рівнів структурно-речовинної організації) дислокаційною структурою. Систематизовані дані про будову «ядра» Мангуської зони відповідають принципу ієрархічності геологічних утворень. Показано, що цей об'єкт є закономірною високовпорядкованою складовою частиною міжблокової зони, що може бути лише наслідком його становлення завдяки залученню всього об'єму середовища Мангуської зони до багатоетапних дислокаційних перетворень. Рудні тіла «ядра» зони всіх рівнів субординації $\epsilon$ закономірними складниками приздвигових структурних малюнків на відповідних рівнях його петро-структурного впорядкування. Виведена схематизована модель багатоетапного становлення докембрійського структурного малюнку центральної частини Приазовського мегаблоку. Відображено, що 3 кожним етапом тектонічних трансформацій кристалічної основи вмісти U й Th у гранітоїдах збільшуються при зменшенні вмісту Th у супракрустальних утвореннях цього мегаблоку. Всі зібрані дані свідчать про формування U-, Th-рудних тіл досліджуваної зони синхронно із вмісними нерудними геологічними тілами, в одних и тих самих геолого-динамічних умовах, тобто в кілька етапів структурно/речовинних перетворень докембрійського фундаменту в умовах деформацій здвигу/ротації.

\section{ЛІТЕРАТУРА}

1. Геологическая карта докембрия восточной части Украинского щита (территория Большого Кривого Рога) и палеозойских (допермских) образований северного склона щита и зоны сочленения с Донбассом. 1: 200000 / Сост. Ю.Б. Бабков, А.Г. Батурина, М.Н. Доброхотов и др. Под ред. М.Н. Доброхотова, Ю.Ю. Юрка. Минво геологии УССР, Киев. 1972. 12 л.

2. Геология и металлогения докембрия Украинского щита. Комплект карт масштаба 1:100 000. Обьяснительные записки / Галецкий Л. С., $\quad$ Горлицкий Б. А., $\quad$ Кипнис Л. А., $\quad$ Клочков В. М., Колосовская В. А. и др. Киев : Мин-во геологии УССР. 1984. 
3. Геолого-геоэлектрическая модель Орехово-Павлоградской шовной зоны Украинского щита / Азаров Н.Я., Анциферов А.В., Шеремет Е.М., Глевасский Е.Б. и др. Киев : Наук. думка, 2005. 190 с.

4. Горяинов П.М., Иванюк Г.Ю. Самоорганизация минеральных систем. Москва : Геокарт, 2001. 315 с.

5. Державна геологічна карта України. М-б 1:200 000. Центральноукраїнська серія. L-37-VIII (Маріуполь), L-37-IX (Таганрог) / Б.В. Бородиня, І.Л. Князькова, Т.Я. Іваненко та ін. Київ : Державна служба геології та надр України, УкрДГРІ, КП «Південукргеологія», 2012.

6. Железисто-кремнистая формация докембрия Мариупольского рудного поля / Отв. ред. Ю.Ю. Юрк. Авт.: Зарицкий А.И., Каныгин Л.И., Кирикилица С.И., Лебедев Ю.С., Левенштейн М.Л., Лучинская Г.Л., Полуновский Р.М., Сухицкая Н.Я., Харагезов М.К. Москва : Недра, 1974. 150с.

7. Железисто-кремнистые формации Украинского Щита. Том I / Отв. ред. Н.П. Семененко, Ладиева В.Д., Бордунов И.Н., Бойко В.Л., Кутин В.В., Струева О.М., Рябоконь С.М., Половко Н.И. и др. Киев : Наук. думка, 1978. 327 с.

8. Закономерности образования и размещения урановых месторождений Украины / Редакционная коллегия: Я.Н. Белевцев, В.Ю. Фоменко, Б.И. Горошников и др. Авторы: М.Я. Абдулина, Л.И. Авдеева, Д.Е. Айзенберг и др. Киев : АН УССР, МИНГЕО СССР, 1968. $763 \mathrm{c}$.

9. Кічурчак В.М., Пігулевський П.Г. Геолого-формаційна карта південно-східної частини УЩ. М 1:500 000. Міністерство охорони навколишнього природного середовища України. ДГП «УкрГеофізика». ДГЕ «ДніпроГеофізика». Київ. 2003.

10. Кравченко Г.Л. До питання про тектоніку Північного Приазов'я. Геологічний журнал. 1965. Т. XXV, вип. 3. С. 56-65.

11. Кореляційна хроностратиграфічна схема раннього докембрію Українського щита / Ссипчук К.Ю., Бобров О.Б., Степанюк Л.М. та ін. УкрДГРІ. Київ, 2004.

12. Лукієнко O.I., Кравченко Д.В., Сухорада А.В. Дислокаційна тектоніка та тектонофації докембрію Українського щита. Київ : ВПЦ Київський університет, 2008. 280 с.

13. Металогенічна карта України. М-б 1:1000 000 / Гол. редактор Д.С. Гурський, автори: В.А. Колосовська, В.А. Веліканов, А.С. Войновський та ін. Київ : Держгеолслужба України, 2002. 6 л.

14. Метаморфические и метасоматические комплексы Приазовья и Южного Донбасса / Горяйнов С.В., Коренев В.В., Аксенов С.В. и др. Харьков : Экограф, 2009. 303 с.

15. Осьмачко Л.С. Західне крило Центрально-Приазовської синформи - складна дислокаційна структура. Вісник Київського 
національного університету імені Тараса Шевченка. Сер. Геологія. 2003. № 25. C. 42-44.

16. Осьмачко Л.С. Типи, умови та етапи формування дислокаційної тектоніки Сорокинської зони та ii обрамлення (із позицій тектонофаціального аналізу) : дис. ... канд. геол. наук : 04.00.04 «Геотектоніка». Київ, 2004. 189 с.

17. Перспективи розвитку торієвої сировинної бази ядерної енергетики України / В.Г. Верховцев, А.В. Кузьмін, М.О. Ярощук, О.О. Крамар, С.Б. Краснов, Г.В. Лисиченко, Л.С. Осьмачко, К.Г. Сущук та ін. Київ : Наукова думка, 2017. 269 с.

18. Полуновский P.М. Литолого-петрографические особенности, стратиграфия и металлогения гнейсовой серии Центрального Приазовья : автореф. дис. ... канд. геол.-мин. наук : 04.00 .01 / ІГФМАНУ. Київ, 1970. 24 с.

19. Родыгин А.И. Признаки направления смещения при деформации сдвига. Томск : Изд-во Томского ун-та, 1991.99 с.

20. Слензак О.И. Локальные структуры зон напряжений докембрия. Киев : Наук. думка, 1984. 102 с.

21. Тектонічна карта України. Масштаб 1:1 000000 та пояснювальна записка / Мін-во охорони навколишнього природного середовища України. Державна геологічна служба. Круглов С.С., Арсірій Ю.О., Веліканов В.Я. та ін. Київ : УкрДГРІ, 2007.

22. Паталаха Е.И., Лукиенко А.И., Гончар В.В. Тектонические потоки как основа понимания геологических структур. Киев : Феникс, $1995.159 \mathrm{c}$.

23. Щербак Н.П., Артеменко Г.В., Лесная И.М. и др. Геохронология раннего докембрия Украинского щита (протерозой). Киев : Наук. думка, 2008. 240 c.

24. State geological map of Ukraine. Scale 1:200 000. Central-Ukrainian series map sheet L-37-VII (Berdyansk). Explanatory notes / Ministry of Ecology and Natural Resources of Ukraine; State geological Survey; State Enterprise «Pivdenukrgeologia» et al. Borodynya B.V., Knyazkova I.L., Esypchuk K.Yu. et al. Kyiv-2004 (2008).

\section{Information about author:} Osmachko L. S., Candidate of Geological Sciences, Senior Researcher SE "Institute of Environmental Geochemistry of the National Academy of Sciences of Ukraine" 34-a, Acad. Palladin Ave., Kyiv, 03142, Ukraine 